\title{
Arachidonate 12-Lipoxygenase, 12R-Type
}

National Cancer Institute

\section{Source}

National Cancer Institute. Arachidonate 12-Lipoxygenase, 12R-Type. NCI Thesaurus. Code C96339.

Arachidonate 12-lipoxygenase, 12R-type (701 aa, $~ 80 \mathrm{kDa}$ ) is encoded by the human ALOX12B gene. This protein is involved in the oxidation of arachidonic acid. 